\title{
Holistic BIM Adoption and Diffusion in Malaysia
}

\author{
Shahela Mamter ${ }^{1, a}$, Abdul Rashid Abdul Aziz² \\ ${ }^{1}$ Faculty of Architecture, Planning and Surveying, UiTM Campus Perak,32610 Bandar Baru Seri Iskandar \\ ${ }^{2}$ School of Housing, Building and Planning, Universiti Sains Malaysia, Pulau Pinang
}

\begin{abstract}
Building Information Modeling is modeling technology and associated set of processes to produce, communicate and analyze digital information models for construction life cycle. Although many benefits can gain by the implementation of BIM, the pace adoption of BIM in Malaysia is still slow. There is an abundance of theories and models purporting to describe the drivers and mechanisms of how new technologies are adopted or diffused into a particular section of society or by individuals or stake players. In addition, many acceptance theories, which imply the adoption of new technologies and can be applied in every sector. This paper aims to present a review of the existing literature of BIM adoption and diffusion theory/model/framework in Malaysia. Researcher revealed the list of driven factors of Holistic BIM Adoption. In addition, it will deal with how to work effectively with groups that initially are relatively
\end{abstract}

Keywords: Building Information Modelling, Holistic, Adoption, Diffusion, Driven Factor

\section{Introduction}

Building Information Modelling (BIM) can be traced back to the parametric modelling research conducted in USA and Europe in the late 1970s and early 1980s, the ArchitectureEngineering-Construction (AEC) industry practically started to implement it in projects from the mid-2000s [1]. During the last seven years, the term BIM has gone from being a buzzword to the centre piece of AEC technology [1]. However, BIM concept has been introduced since 1970 by Professor Charles M. Eastman [1] and the United States of America (USA) becomes the pioneer country that implements the BIM [2]. Furthermore, BIM as the method is supportive of collaborative planning, facilitating communication and information exchange among various planning process participants [3]. According to [4] BIM is an innovative new approach to building design, construction and management which are introduced by Autodesk in the year of 2002 in order to change the way of professional worldwide think on how technology can be applied to building design, construction and management. In United Kingdom, 2016 will be the targeted year towards BIM level 2 adoptions on all centrally-procured projects. The hurdle that was facing the industry is standardisation of working between clients and supply chain [5].

Further, lack of understanding of BIM and how it can be integrated into the construction industry within the various professional disciplines also apart of problems in the implementation of BIM [6]. However, BIM has recently attained widespread in the Architectural, Engineering and Construction (AEC) industry, especially in the U.S and U.K. However, the adoption is still low in the local industry. In Malaysia [7] conclude that a close coordination among the industry stake holders with a specific vision and environment needs to be developed in AEC industry to enjoy the fruitful benefits of BIM implementation. The support by the concerned authorities, extensive consultation between the professional and industry practitioners is the only key to success. The question arises whether the all BIM stake players in Malaysia are well aware and how far the knowledge about BIM in the Malaysian construction industry. Besides that, [8] found in Malaysia, the developments of BIM still an infancy stage, but it has gained serious attention from many players. However despite receiving massive attention within the AEC industry, it appears that the adoption rate is not representing such phenomenon. Khor Wei Moon, director of technical design for Sunway Group, a property development and construction company, found that BIM was "mainly a private initiative driven by the larger property developers and contractors" in Malaysia [9]. 
The inconsistency of adoption rate exists not only between countries but between industry stake players as well [10]. For better understand the driven factors of BIM adoption and the stake players influencing the adoption need to be investigated. In Addition, [11] conclude there is no clear holistic approach or methodology to assess adoption of BIM adoption at the corporate level down to project level.

Accordingly, the authors are conducting research with an attempt to establish the theory of BIM adoption as to highlight the positive action by putting the BIM into the construction industry. Finally, the study will reveal a Holistic BIM Adoption Model based on the deductive and inductive holistic driven factors.

\subsection{Research Aims and Objectives}

This conceptual paper is primarily based on the thorough review of the relevant literature of BIM adoption theory/model/framework in Malaysia and the driven factors for holistic BIM Adoption. Drawing from the research problem highlighted, the pertinent research objectives are:

i. To identify which theory/ model/ framework can best capture holistically the issues surrounding the low adoption of BIM in Malaysia.

ii. To determine the driven factors influencing the holistic adoption of BIM.

\subsection{BIM Adoption/ Theory/ Framework in Malaysia}

Many of the recent BIM adoption model/theory/frameworks is related studies emphasize the development of an application BIM technology based on micro adoption. Moreover, influential factors are systematically listed, many of them focus only on the Technology Acceptance Models have provided a basis for investigating the role and impact of perception and behavioural disposition towards technology usage based on psychological theories. Its validity supported by [12] which concentrating on research methodological approach from dominant IT field and management perspectives in humanIT interaction, in an attempt to further improve BIM adoption. It has a narrow conception of TAM theory and organisational readiness framework. Besides that, [10] produced a model by integrating Diffusion of Innovation (DOI) Theory, Institutional Theory and fit into TechnologyOrganisation- Environment (TOE) framework. It does not cater to examine the relationship of existing BIM theory/model/framework with the Government policy makers. It also suggested by [13] BIM in Malaysia needs a pan-industry champion with authority. As such, the individual is most likely to come from the Government sector. In addition, [14] revealed the organisational framework readiness in implementing BIM. It narrowly focuses on the relationship between people, process, technology and business process re-engineering in Malaysian design consultant. However, none of the approaches studied focussing on the causal loops amongst all driven BIM factors due holistic implementation of BIM in Malaysia. [12] recommend further extension study focusing on extending the existing model with other previously unperceived constructs, input of other previously unperceived relationship mediators, selections of other industry players such as clients and software developers and a cross-sectional survey in other countries with similar BIM maturity stages. Therefore, the researcher aims to provide a Holistic Theory/Model/Framework BIM adoption in further study. Table 1 show the review of Malaysian BIM adoption theory/model/framework from previous researcher. It will shed useful information for construction researchers and practitioners in exploring the BIM adoption and diffusion theory in Malaysia.

Table 1: The previous research on Malaysian BIM Adoption Theory

\begin{tabular}{|c|c|c|c|}
\hline No. & $\begin{array}{l}\text { Theory/Model } \\
\text { /Framework }\end{array}$ & $\begin{array}{c}\text { Author / } \\
\text { Year }\end{array}$ & Explanations \\
\hline 1 . & $\begin{array}{l}\text { Technology } \\
\text { acceptance } \\
\text { model Davis } \\
(\text { TAM) (1985) }\end{array}$ & $\begin{array}{l}{[12][13]} \\
{[15][16]}\end{array}$ & $\begin{array}{l}\text { TAM models } \\
\text { how users come } \\
\text { to accept and use } \\
\text { a technology by } \\
\text { identifying } \\
\text { factors that } \\
\text { cause people to } \\
\text { accept and make } \\
\text { use of systems } \\
\text { developed and } \\
\text { implemented by } \\
\text { others. } \\
\text { The model } \\
\text { suggests that } \\
\text { when users are } \\
\text { presented with a } \\
\text { new technology, } \\
\text { a number of } \\
\text { factors influence } \\
\text { their decision } \\
\text { about how and } \\
\text { when they will } \\
\text { use it. }\end{array}$ \\
\hline 2. & $\begin{array}{l}\text { Diffusion of } \\
\text { Innovation } \\
\text { Theory Rogers } \\
{[17]}\end{array}$ & {$[13][10]$} & $\begin{array}{l}\text { Five categories } \\
\text { that emerged } \\
\text { with the } \\
\text { following } \\
\text { profiles: } \\
\text { 1) Innovator } \\
\text { s- } \\
\text { ventureso } \\
\text { me, } \\
\text { educated, } \\
\text { multiple } \\
\text { info } \\
\text { sources; } \\
\text { 2) Early } \\
\text { adopters - } \\
\text { social } \\
\text { leaders, } \\
\text { popular, } \\
\text { educated; }\end{array}$ \\
\hline
\end{tabular}




\begin{tabular}{|c|c|c|c|}
\hline & & & 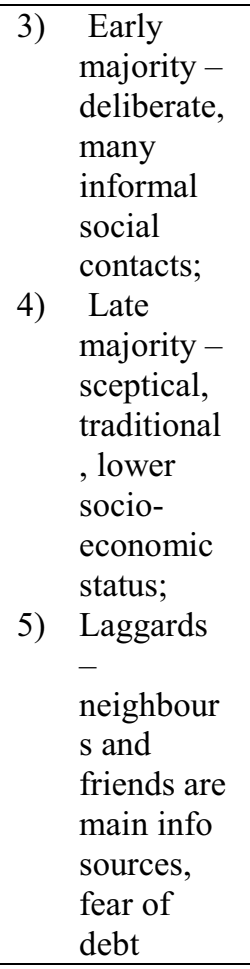 \\
\hline 3. & $\begin{array}{l}\text { Institutional } \\
\text { Theory [18] }\end{array}$ & {$[13][10]$} & $\begin{array}{l}\text { Three } \\
\text { pressures are: } \\
\text { 1) Mimetic } \\
\text { pressures } \\
\text { is } \\
\text { adoption } \\
\text { of IT } \\
\text { 2) Coercive } \\
\text { pressures } \\
\text { which are: } \\
\text { agencies, } \\
\text { suppliers, } \\
\text { customers } \\
\text {, parent } \\
\text { corporatio } \\
\text { ns and } \\
\text { other key } \\
\text { constituen } \\
\text { ts } \\
\text { 3) Normativ } \\
\text { e } \\
\text { pressures } \\
\text { which are: } \\
\text { profession } \\
\text { al bodies, } \\
\text { consultant } \\
\text { s, trade } \\
\text { associatio } \\
\text { ns }\end{array}$ \\
\hline 4. & $\begin{array}{l}\text { Technology- } \\
\text { Organisational } \\
- \\
\text { Environmental } \\
\text { (TOE) } \\
\text { framework }\end{array}$ & [10] & $\begin{array}{l}\text { Focused into } 3 \\
\text { contexts which } \\
\text { are } \\
\text { Technological, } \\
\text { Organisational } \\
\text { and }\end{array}$ \\
\hline
\end{tabular}

\begin{tabular}{|c|c|c|c|}
\hline & & & $\begin{array}{l}\text { Environmental } \\
\text { factors. }\end{array}$ \\
\hline 5. & $\begin{array}{l}\text { Organisational } \\
\text { Readiness } \\
\text { Framework }\end{array}$ & [14] & $\begin{array}{l}\text { The readiness } \\
\text { element found, } \\
\text { which are: } \\
\text { 4) Process: } \\
\text { Change } \\
\text { Strategy, } \\
\text { BIM } \\
\text { Implemen } \\
\text { tation } \\
\text { Managem } \\
\text { ent, and } \\
\text { Policy. } \\
\text { Managem } \\
\text { ent: } \\
\text { Business } \\
\text { Strategy, } \\
\text { Managem } \\
\text { ent } \\
\text { Competen } \\
\text { cy, and } \\
\text { Leadershi } \\
\text { p. } \\
\text { Technolo } \\
\text { gy: } \\
\text { Hardware, } \\
\text { Technical } \\
\text { Support, } \\
\text { and } \\
\text { Software. } \\
\text { 7eople: } \\
\text { Roles and } \\
\text { Responsib } \\
\text { ilities, } \\
\text { Skill and } \\
\text { Attitude, } \\
\text { Training } \\
\text { and } \\
\text { Education } \\
\text { and Work } \\
\text { Environm } \\
\text { ent }\end{array}$ \\
\hline
\end{tabular}

\subsection{BIM Levers for Holistic Adoption in Malaysia}

Collaboration with government key agencies also converges in the promulgation of laws and policies, contract and procurement and others. Collaboration with professional bodies, academia, committees and AEC stakeholders will ensure BIM implementation at the competitive level. Therefore, BIM levers in Malaysia are:

\section{a. Construction Industry Development Board (CIDB)}

Figure 2 shown, CIDB will complement the efforts by providing a sustainable environment where BIM will survive and thrive. Early efforts include providing 
awareness programs and workshops with the industry to gather feedback and comment aimed at charting the way forward for a holistic implementation of BIM. CIDB is also in the midst of establishing the National BIM Committee of Building Information Modelling in construction Industry in order to coordinate the movement of BIM in the country [19]

\section{b. Jabatan Kerja Raya Malaysia (JKR)}

BIM committee in JKR was formed by the government on 27 August 2007 to choose the right BIM platform to ensure interoperability. The purpose of forming the committee was to identify construction project processes that involved BIM implementation. Moreover, the committee also prepared a BIM standard manual documentation for Malaysian public work department as a guideline for construction players' reference. The committee also provides BIM training and advisory assistance to project teams in using BIM tools since 2011 [20].

\section{c. Private Company}

BIMASIA Sdn Bhd is Malaysia leading Building Information Modelling (BIM) Consultancy firm established in 2013. The list services provided are management, modelling, strategy and training tailor made to individual existing office workflow for Architects, Engineers, Developers and Construction companies. This firm has a strong reputation for world-class design of BIM coordinated buildings within Master planning, Retail-led Mixed Use Developments, Offices, Residential and Hotels [21]

\section{d. Policy}

Malaysian Government policy was the critical factor that heavily influenced the promotion of new techniques or products especially in the construction sector [22]. Government policy has been noted as one of the key influences in promoting a new technique or products in the construction industry, simply because the government is one of the biggest clients in any construction industry. The importance of policies in achieving successful of BIM implementation which UK Government will require fully collaborative 3D BIM (with all project and asset information, documentation and data being electronic) as a minimum by 2016 [23].

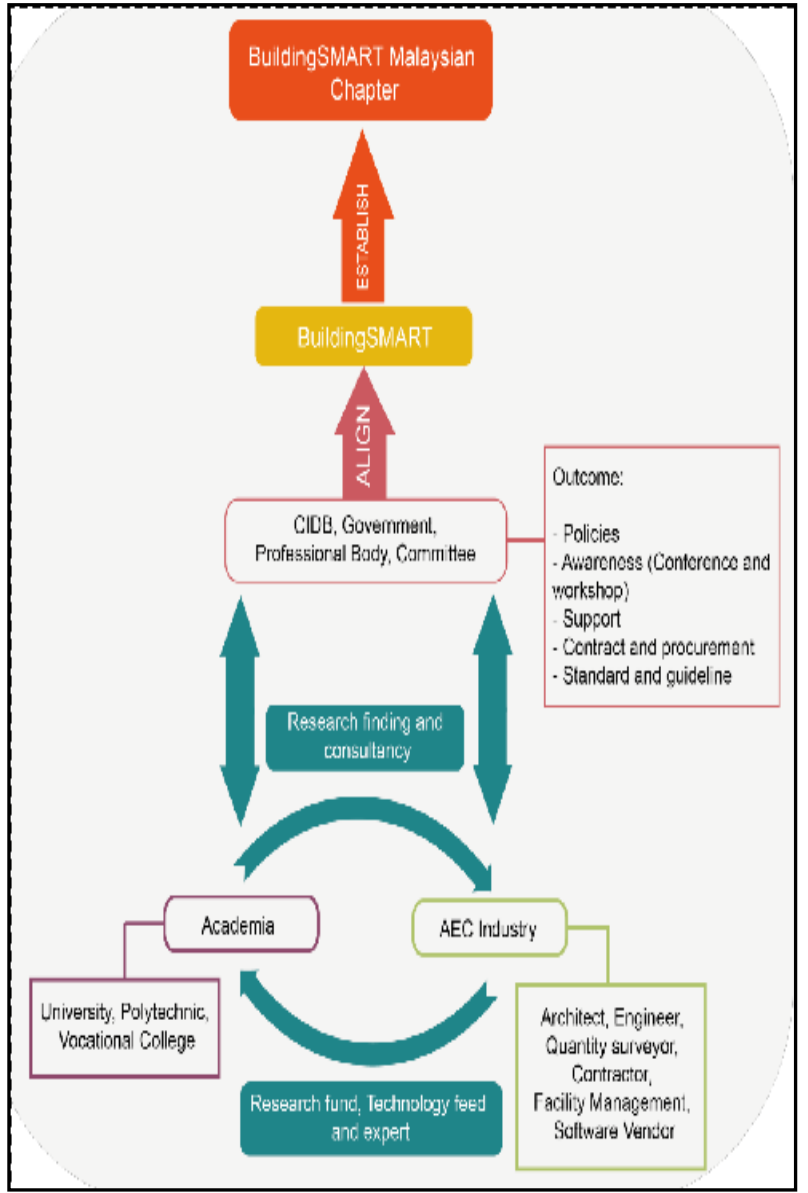

Figure 1: Collaborative Framework for BIM Adoption in Malaysia (source: [24])

\subsection{BIM Driven Factors}

According to the literature review BIM driven factors are summarized in Table 2 below. The driven factors classified into 6 country pioneers in advocating the adoption of BIM: United Kingdom: [1][23] [25][26][27] [28][29], South Korea: [30] [31], Taiwan: [11][32], Singapore: [33][2][34], Hong Kong: [35], New Zealand and Australia: [36]. Therefore, the table was tabulated based on the $5 \mathrm{sub}$ theme: Policy, Engagement, Investment, Implementation, and Education were identified within the 16 references cited by this paper. Each driven factors was ticked with an "X". The selection of sub theme was based on the researcher selection. Currently, the researcher have undertaken a preliminary quantitative study in order to ensure that it is comprehensive, up-to-date and appropriate for the precise needs of the study. By understanding the driven factors for BIM adoption, Malaysian BIM Player will be better able to allocate sufficient resources to achieve its goal. Under Francis Maude, Minister for the Cabinet Office, the UK government was implemented a construction strategy that stated BIM will be a key part of the government's procurement of public buildings and, by 2016, model-based BIM was mandatory on all public sector projects, included delivery of all project and asset information, documentation and data [9]. 


\section{Conclusion}

This paper revealed the review of BIM adoption theory/model/framework in Malaysia. The majority of researcher concentrating on organisation/or individual for implementing BIM in Malaysia. Furthermore, the researcher found that could indicate a causal loop model for holistic BIM implementation among Malaysian construction stake players. The proposed causal loop model will give the high impact contribution for BIM implementation. The higher the financial benefits, the greater the pressure on the government to provide the funds [37]. Moreover, the feedback capability of the Holistic BIM adoption model is of special interest to policy-makers in which they can simulate possible scenarios for different policies. Currently, the authors have undertaken a further empirical research using expert opinion survey approach to collect detailed quantitative data information regarding holistically driven factors in adopting BIM. The findings will be revealed for the next research publication

\section{Acknowledgements}

The authors acknowledge the support from Universiti Teknologi MARA Perak Branch, Campus Seri Iskandar and Malaysia Ministry of Education. 


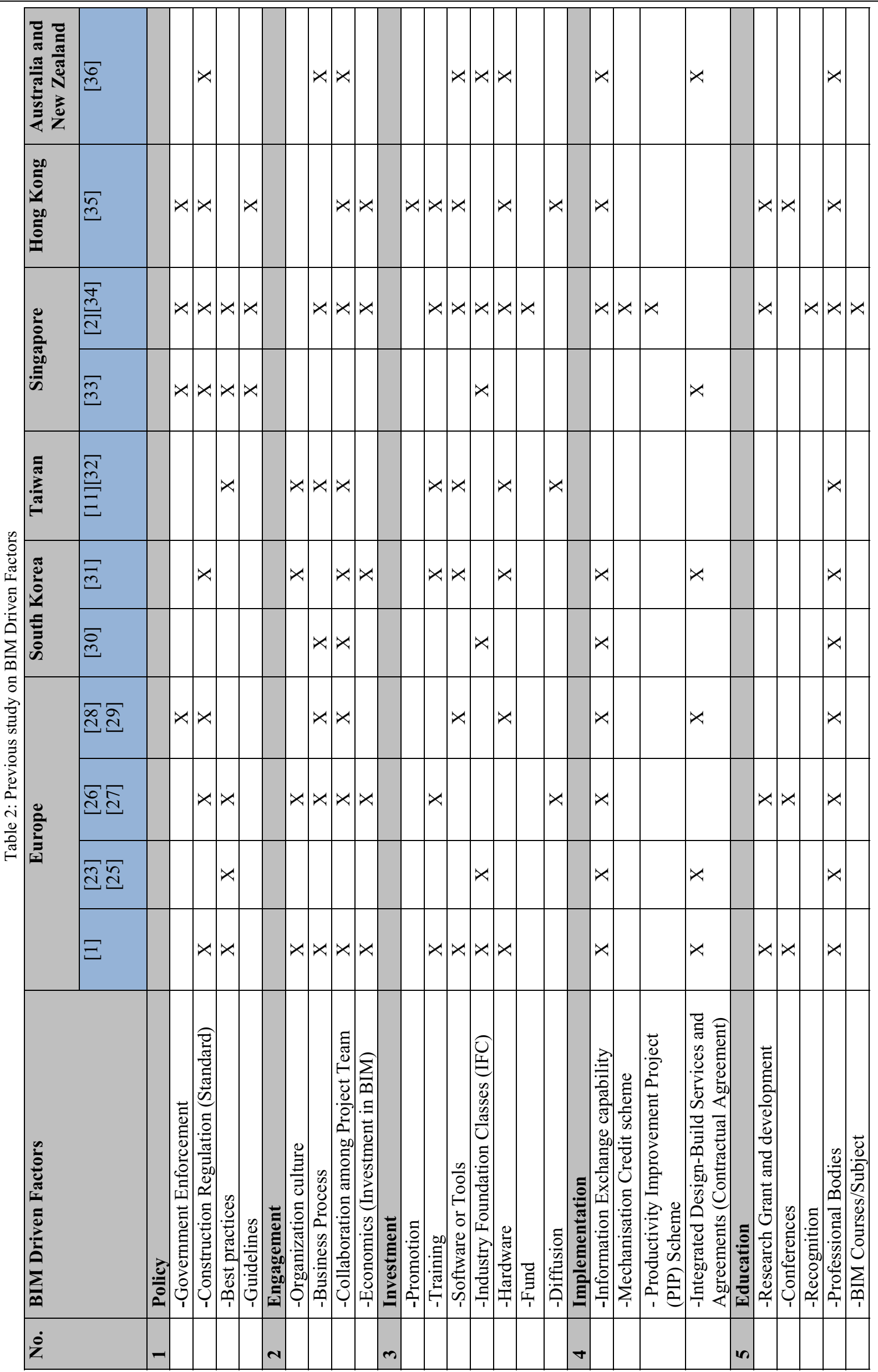




\section{References}

[1] C. Eastman, P. Teicholz, R. Sacks, and K. Liston, BIM Handbook: A Guide to Building Information Modeling for Owners, Managers, Designers, Engineers and Contractors, vol. 2. 2011.

[2] BCA, "The BIM Issue," Build Smart Mag., no. 9, p. 4, 2011.

[3] R. Sebastian and L. van Berlo, "Tool for Benchmarking BIM Performance of Design, Engineering and Construction Firms in The Netherlands," Archit. Eng. Des. Manag., vol. 6, no. 4, pp. 254-263, 2010.

[4] Autodesk, "Building Information Modeling in Practice," Autodesk Build. Solut. White Pap., pp. 1-6, 2002.

[5] "BIM today_A clear view." Adjacent Digital Politics Ltd.ISSN 2058-9611, England \& Wales, p. 90p, 2016.

[6] N. Thurairajah and D. Goucher, "Advantages and Challenges of Using BIM : a Cost Consultant 's Perspective," B49th ASC Annu. Int. Conf. Proceedings. Copyr. 2013 by Assoc. Sch. Constr., pp. 18, 2013.

[7] S. S. S. Gardezi, N. Shafiq, M. F. Nurudinn, S. A. Farhan, and U. A. Umar, "Challenges for Implementation of Building Information Modeling (BIM) in Malaysian Construction Industry," Appl. Mech. Mater., vol. 567, no. JUNE, pp. 559-564, 2014.

[8] Z. Zahrizan, N. M. Ali, A. T. Haron, A. Marshall-ponting, and Z. Abd, "Exploring The Adoption of Building Information Modelling ( BIM ) in the Malaysian Construction Industry: A Qualitative Approach," IJRET Int. J. Res. Eng. Technol. eISSN 2319-1163 | pISSN 2321-7308, pp. 384-395, 2013.

[9] McGraw-Hill Construction, The Business Value of BIM for Construction in Major GLobal Markets: How contractors around the world are driving innovation with Building Information Modeling. 2014.

[10] J. Osman, S. Mazlina, S. Khuzzan, and A. Razaksapian, "Building Information Modelling: Proposed Adoption Model For Quantity Surveying Firms," no. June, pp. 151-165, 2015.

[11] M.-H. Tsai, M. Mom, and S.-H. Hsieh, "Developing critical success factors for the assessment of BIM technology adoption: part I. Methodology and survey," J. Chinese Inst. Eng., vol. 3839, no. April 2015, pp. 114, 2014.

[12] W. Imoudu Enegbuma, U. Godwin
Aliagha, and K. Nita Ali, "Preliminary building information modelling adoption model in Malaysia," Constr. Innov., vol. 14, no. 4, pp. 408-432, 2014.

[13] J. P. Rogers, "The strategic adoption of building information modelling by Malaysian engineering consulting services firms The Strategic Adoption of Building Information Modelling by Malaysian Engineering Consulting Services Firms," 2013.

[14] A. T. Haron, "Organisational Readiness To Implement Building Information Modelling: A Framework For Design Consultants In Malaysia," p. 285, 2013.

[15] H. Son, S. Lee, and C. Kim, "What drives the adoption of building information modeling in design organizations? An empirical investigation of the antecedents affecting architects' behavioral intentions," Autom. Constr., vol. 49, pp. 92-99, 2015.

[16] S. Lee, J. Yu, and D. Jeong, "BIM Acceptance Model in Construction Organizations," J. Manag. Eng., vol. 31, no. 1988, p. 04014048, 2013.

[17] E. M. Rogers, Diffusion of innovations. 1995.

[18] W. R. Scott, "Institutional theory: contributing to a theoretical research program," Gt. Mind Manag. Process Theory Dev., no. JANUARY 2005, 2005.

[19] "BIM roadmap CIDB," 2014.

[20] M. P. W. D. PWD, "Unit Building Information Modeling (BIM)," 2013. [Online]. Available: https://www.jkr.gov.my.

[21] Shenhua Group Corporation Ltd, "Company Profile," 2010.

[22] M. Nasrun, M. Nawi, and U. Utara, "Critical Success Factors for Improving Team Integration in Industrialised Building System ( Ibs ) Construction Projects : the Malaysian Case Integration in Industrialised Building System ( Ibs )," no. November 2015, 2012.

[23] S. Hamil, A. Malone, P. Conaghan, M. Packham, R. Holland, A. Kemp, P. Jackson, E. Tuttle, J. Fiske, S. Fray, and A. Dobson, "NBS National BIM Report 2015 Introduction Richard Waterhouse CEO, NBS and RIBA Enterprises," 2015.

[24] CIDB, BIM Roadmap for Malaysia's Construction Industry, no. Series 2. 2014.

[25] McGraw-Hill Construction, H. M. Bernstein, S. A. Jones, and J. E. Gudgel, "The Business Value of BIM in Europe: Getting Building Information Modeling to 
the Bottom Line in the United Kingdom, France and Germany," 2010.

[26] F. Khosrowshahi and Y. Arayici, "Roadmap for implementation of BIM in the UK construction industry," Eng. Constr. Archit. Manag., vol. 19, no. 6, pp. 610-635, Nov. 2012.

[27] A. Grilo and R. Jardim-Goncalves, "Value proposition on interoperability of BIM and collaborative working environments," Autom. Constr., vol. 19, no. 5, pp. 522-530, 2010.

[28] T. B. Allen Wan ${ }^{1}$, Andrew Platten, "STUDY OF SAFETY AUDITORS' VIEWS ON THE USE OF BIM FOR SAFETY IN HONG KONG," in 1st BIM UK Academic Conference, 2012, vol. 1, p. 233.

[29] R. Morlhon, R. Pellerin, and M. Bourgault, "Building Information Modeling Implementation through Maturity Evaluation and Critical Success Factors Management," Procedia Technol., vol. 16, no. 0, pp. 1126-1134, 2014.

[30] McGraw Hill Construction, The Business Value of BIM in South Korea. 2012.

[31] J. Won, G. Lee, and C. Lee, "Comparitive Analysis of BIM Adoption in Korean Construction Industry and Other Countries,"
Iccem \& Iccpm, 2009.

[32] M. Mom, M. H. Tsai, and S.-H. Hsieh, "On Decision-Making and TechnologyImplementing Factors for BIM Adoption," Int. Conf. Constr. Appl. Virtual Real., no. Succar 2009, 2011.

[33] A. K. D. Wong, F. K. Wong, and A. Nadeem, "Comparative roles of major stakeholders for the implementation of BIM in various countries," BIM-implementation, 2009.

[34] B. and C. Authority, Singapore BIM Essential Guide For BIM Adoption in an Organization. 2013.

[35] A. K. D. Wong, F. K. W. Wong, and A. Nadeem, "Government roles in implementing building information modelling systems: Comparison between Hong Kong and the United States," Constr. Innov. Information, Process. Manag., vol. 11, no. 1, pp. 61-76, 2011.

[36] McGraw Hill Construction, "The Business Value of BIM in Australia and New Zealand: Smart Market Report," 2014.

[37] S. Ahmad, "Simulating the Effect of FeedIn Tariff on Renewable Energy Penetration: A System Dynamics Approach," no. November 2014, 2015. 